\title{
Development of Water Quality Indices (WQIs): A Review
}

\author{
Talent Diotrefe Banda, Muthukrishna Vellaisamy Kumarasamy* \\ Civil Engineering Programme, School of Engineering, University of Kwazulu-Natal, \\ Howard College, Durban, South Africa
}

Received: 10 February 2019

Accepted: 8 July 2019

\begin{abstract}
Various physical, chemical and biological variables are considered detrimental to the aquatic environment, especially if contained in excessive amounts. Such parameters originate from anthropogenic and natural sources. Though some might be essential in the aquatic ecosystem, they might pose a serious risk if present in excessive concentrations. Eventually, monitoring and assessing water resources becomes mandatory in order to trace the levels and effects of such physio-chemical and biological parameters. And the common practical method is through the application of water quality indices (WQIs). This prompts the need to further exploit the use of WQIs and continuously modify such important tools in order to become better, simpler and more appropriate toward water resource management needs; which needs are dynamic and forever changing. The current study focuses on developing a universal water quality model for South African river catchments. And as part of the study, this review work attempts to outline the objectives of establishing water quality monitoring tools, their classification and the basic procedure of developing WQIs.
\end{abstract}

Keywords: Delphi method, analytical hierarchy process (AHP), aggregation methods, sub-indices, water quality index score

\section{Introduction}

Water quality indices (WQIs) are necessary for simplifying the reporting of complex and technical water quality information. They are scientifically based communication models that are capable of converting multi-variable water quality data to produce a single unit less digit score that describes overall water quality. This in turn is important for providing a structured

*e-mail: kumarasamy@ukzn.ac.za platform to evaluate and compare water quality of various water resources [1,2]. Water quality indices are not aimed at replacing detailed water quality analysis, rather they are tools aimed at providing a quick guide to assist water quality experts, policymakers and the public by communicating water quality data in a more consistent and on-going manner [2, 3].

Following the studies by Poonam, et al. [2], Lumb et al. [4], Sutadian et al. [5], and Paun et al. [6], it has been noted that most WQIs are designed for a particular region and are source-specific, thus creating a gap and ample scope to develop a universally acceptable WQI. However, it is extremely difficult to develop a water quality model that is globally acceptable, hence 
the current studies only focus on national boundaries; that is, a model only applicable to South African river catchments.

Though seemingly problematic to deal with in prospect, it is pertinent and recommended that water quality experts embark on developing a unified model that can be utilized across the globe. But the immediate mission is to develop nationally acceptable water quality indices and break the barrier of region-specific models. The tool must provide a basic platform to measure whether specific water resources need to be restored and to what degree. Thus, assisting in the prioritization of water quality activities in South Africa. In respect to this, the authors attempt to outline the basic procedures followed when developing WQIs, and this review work forms part of the main objective of developing a universal water quality index and water quality variability model for South African river catchments.

\section{Objectives of Establishing Water Quality Monitoring Tools}

The world has experienced continuous growth in socio-economic activities, but such progression has been accompanied by accelerated growth in water contamination, causing pollution stress in the aquatic environment [7, 8]. Undoubtedly, this evolution of water pollution has led to the development of numerous WQIs as water quality monitoring tools [2]. The development of such tools can be based on either (i) a single-objective monitoring process, whereby it addresses a specific single problem area or (ii) a multi-objective monitoring process, which covers various water applications and provides data for more than one assessment programme [7].

According to the World Health Organisation [9], global water quality monitoring objectives are defined in order to address the public, government institutions, the scientific and research community, water economists and policymakers for water quality assessment. The specific objectives of water quality monitoring programmes are modelled specifically to:

(i) Define the water quality status and assist in identifying the most favorable action, relative to human and aquatic ecosystem health.

(ii) Describe water quality trends, thereby providing a platform to outline crisis stages.

(iii)Delineate the source of water quality trends and dominant circumstances.

(iv)Identify and cluster the types of water quality problems experienced in specific catchment areas.

(v) Provide water quality assessment information in a structured format that can be easily understood by water resource management and regulatory agencies when evaluating alternatives and making necessary decisions.

In view of water quality monitoring objectives, the water quality index is therefore a useful statistical tool and it must interpret complex water quality information and deduce it into a single numeric value, thus validating various WQIs for appropriate application across various catchments is the aim of this study.

\section{Classifying Water Quality Indices}

Poonam, et al. [2] classified WQIs into four main categories. The first three are grouped according to their application and the fourth is based on the formation technique rather than the purpose of establishment. Statistical approaches are formulation techniques, thereto substituting the Delphi method of establishing parameters, sub-indices and weights. It is therefore subjective to consider the design method when classifying WQIs. For the purpose of this review, however, categorization of water quality indices is based on the purpose of establishment and the groups are as follows:

(i) Public indices: created for general water quality assessment irrespective of the intended water usage. Basically, their evaluation process is independent from the purpose and application of the water reserve - a practical example being the National Sanitation Foundation Water Quality Index [10].

(ii) Specific indices: developed for specific application, such as drinking, irrigation, industrial and ecosystem preservation. The Vaal Water Quality Index (WQI) developed by Banda [11] is an example of a specific index created to evaluate the status of surface raw water intended for treatment to portable standards. Another example is from Argentina, where Almeida et al. [12] developed a water quality index particularly for the assessment of recreational water resources.

(iii) Planning indices: these are water evaluation tools, purposefully designed to assist water managers and policymakers to substantiate their decisions regarding water quality. The United States of America developed such an index for routine stream monitoring [13].

Generally, WQIs are not designed for broad application - they are customarily developed for a specific watershed and or region, unless otherwise if different basins share the same water quality monitoring objectives and test the same range of water quality variables. The choice and selection of water quality variables to be incorporated in an index is governed by the proposed uses of the water quality index. The combined effect of such technicalities eventually demarcates the application boundaries of the indexing model [11]. This is, perhaps, the most demanding scientific need; that is, the development of a unified water quality index that can be applicable to most - if not all - of the watersheds in South Africa. An index that is not limited to certain application boundaries is thus the aim of this study. 


\section{Basic Procedure for Developing a Water Quality Index}

A considerably number of indices have been developed since the primary index by Horton [14], but regardless of such efforts, there is still no globally acceptable manner in which water quality indices are developed [5]. However, there is a certain possible trend, which is distinguished by the following common steps [2, 6, 15-18]:

(i) Selection of parameters: identifying and choosing the most critical variables suitable to provide a functional sense to the water quality index. Proficiency is required in order to provide just enough parameters - not too few or too many. This process can be done by either expert opinion (whether individually or as a group) or through statistical techniques.

(ii) The formation of sub-index values: considering that various water quality parameters have different scientific units, it becomes necessary to transform them into a single common scale, and this task is achieved by generating sub-indices.

(iii) Establishing weights: weightage is assigned to each variable based on the level of importance of each parameter, established through evaluating the potential impact of each parameter when their concentration levels are outside the permissible limits. Though Delphi is a tedious process, the method will minimize subjectivity in establishing weights and enhance credibility of the index.

(iv)Aggregation of sub-indices: this if the final step toward obtaining a final cumulative index value. In understanding the assigned weights, mathematical models are used to combine all the sub-indices into one index number. They are various aggregation methods available, but there are three fundamental models commonly used. These are additive, multiplicative and logical functions.

Of late, several attempts have been made to explore the structure and relationship of water quality variables using statistical approaches like cluster analysis, discriminant analysis, factor analysis and principal component analysis [19-21]. Even the application of artificial intelligence methods, which includes fuzzy logic and artificial neural networks, has been tested with the aim of reducing prejudice and improving on the reliability of the water quality index models [2, 22$26]$. Further details regarding the steps and procedures of developing a WQI are discussed at length in the subsequent sections of this review paper.

\section{Selection of Water Quality Parameters}

Water quality variables are the most important constituents of any water quality index. They are the basis at which the index value is generated. Consequently, the selection of such parameters becomes an essential step in the establishment of an index. The selection process is done in understanding the hazard and risk posed by different pollutants. Emphasis is given to water quality variables that have more impact in disturbing environmental and human health whenever their concentration levels exceed tolerable limits. [2732]. In order to critically ascertain the influence of each variable, one has to establish the intended use of the water body, since acceptability and level of impact differs with each application. Therefore, it is equally important to note that the selection of parameters used to evaluate water quality depends largely on the envisioned use of the water body [33]. Accordingly, the parameter selection process becomes apprehensive with uncertainty and subjectivity, as it is aligned to the usefulness of the water quality index. It then becomes crucial to exercise enormous care and sound judgement in order to reduce the ambiguity and ensure that the most representative parameters are included in a WQI [15].

According to Sutadian et al. [5], three systems are applicable to the parameter selection process. The three categories are defined as follows:

(a) Fixed system: in this case, the application of the WQI is limited to a fixed set of parameters that are selected by the WQI developer as the most suitable set of variables necessary for calculating the final index value. Although using a fixed set of parameters allows the user to appropriately analyze and compare water quality status among different sites, the system is rigid, which is a common problem with most water quality indices. Even if it becomes necessary and important to include additional variables in the index, a fixed system cannot accommodate the addition of new parameters, hence the term rigid.

(b) Open system: a flexible system that permits the user to incorporate parameters of their choice. Though such WQIs are flexible and eliminate rigidity, they pose a critical problem in comparing results from different monitoring sites. Unless otherwise the use of a similar set of parameters is enforced by the user, it is then inappropriate to apply such indices (open system) as comparison tools - especially when generating priority matrices based on pollution status and water quality classification.

(c) Mixed system: a combination of the fixed and open systems. The system consists of the basic fixed set of parameters that are compulsory for calculating the index value, as well as additional parameters that can be input based on user discretion.

Although the mixed system is the best fit between the fixed and open systems, the mixed system still suffers from the same problem with the open system, though with a reduced margin of error. Considering the advantages and disadvantages of the three systems, the fixed system is designed to analyze and compare water quality parameters, making it the most appropriate system suitable for the development of a unified WQI that can be functional in most if not all the catchments in South Africa, and which is the main aim of our study. Parameter selection for a fixed system requires 
enormous care, attention, experience and proficiency in order to ensure that the most significant variables are incorporated in the WQI. Expertise is required to delineate what is regarded as too few or too many variables; the ability to optimize the ideal number of parameters necessary or just enough to calculate a meaningful water quality index value. The selection procedure can be performed using expert opinion (either as a group or individually), or by means of statistical methods.

Due to human influence, the expert opinion method can be subjective and uncertain. In an attempt to reduce the subjectivity in parameter selection, statistical tools have been developed and widely adopted as common practice $[15,20,34-36]$. Hypothetically, this might be the most objective method, but still, the human influence is evident on the choice of data that is statistically analyzed, hence compromising the accuracy of the procedure [5]. Nevertheless, through the use of pattern recognition; statistical methods remain the most powerful technique for interpreting the variance between a large number of variables and convert them into smaller groups of independent variables [34, 36].

Lessening the monitoring data requirements governs the input parameter demand and reduces the bulkiness of the indexing model. In this way, it intensifies regular use of the index and promotes the application of the indexing model. On the basis thereof, the water quality parameters should be reduced to an optimum - just enough to ensure functional sense and scientific steadiness. Against this background, the most-considered parameters for developing a water quality index are: ammonia $\left(\mathrm{NH}_{3}\right)$, calcium $(\mathrm{Ca})$, chloride $(\mathrm{Cl})$, chlorophyll a (Chl-a), electrical conductivity (EC), fluoride (F), hardness $\left(\mathrm{CaCO}_{3}\right)$, magnesium $(\mathrm{Mg})$, manganese $(\mathrm{Mn})$, nitrate $\left(\mathrm{NO}_{3}\right)$, pondus Hydrogenium $(\mathrm{pH})$, sulphate $\left(\mathrm{SO}_{4}\right)$ and turbidity (Turb) [10, 11, 14, 37-66, 67]. Conclusively, the selection of the maximum allowable variables that can effectively classify and describe the degree of water quality is not always straightforward. Nonetheless, the above 13 water quality parameters are the definite key contaminants regarded as the most frequently monitored variables, with concentrated pollution effects, and the most dangerous variables with obdurate legal restrictions in water quality regulations. Accordingly, they have significant effects on water quality, which justify their inclusion as input parameters toward the development of water quality models.

Water quality parameters are measured in different scientific units, and in order to transform them into a single index value their scientific units have to be transformed into a common scale. This process is achieved by the application of mathematical sub-indices.

\section{Formation of Sub-Indices}

Considering the fact that water quality variables are measured in various units, sub-indices are mathematical tools utilized to transform the scientific units into a common non-dimensional scale. Most of the traditional WQIs can only aggregate parameters with a common scale, hence the process of standardizing and rescaling parameter values is necessary. However, a few water quality indices do not have such a functionality. Instead, the actual measured parameter values are used to calculate the final index value [5]. For example, CCME [28] established a multivariate statistical formula to aggregate the original parameter values without the application of sub-indices. In a similar case, Said et al. [68] developed a mathematical equation that calculates the final index value without standardizing the actual measured parameter values. Depending on the aggregation technique being employed, variables can be considered directly as sub-indices and aggregated into a single index value, whereas in some instances the primary parameter sub-indices can be further grouped and aggregated into a bigger secondary group of subindices, which are then later aggregated into the final index value. Such are often composite or aggregated sub-indices, and a practical example is Bhargava [69], which have four different composite sub-indices in the form of organic and inorganic, coliforms, heavy metals and physical sub-indices [5]. The mathematical relationships between the measured parameter values and the sub-index values are referred to as the sub-index functions. The actual parameter values can be translated to sub-index by means of sub-index functions, which can be presented graphically as rating curves (parameter values plotted to the corresponding sub-index values). There are three common methods used to develop subindex functions, that is: (1) expert judgement or opinion, which can be done either individually or as a group, (2) use of water quality standards or regulations, and (3) statistical methods [5].

\section{Expert Judgement}

Similar to the selection of water quality parameters, either individual or group expertise and skills are utilized to establish sub-index functions. In this method, key points of the rating curves are established from personal opinion and plotted graphically to represent the impact of each parameter at different concentration levels. The process can be done individually, but involves a number of experts in order to minimize partiality and ambiguity. In the event that a group of water experts are involved, the Delphi method can be employed, whereby questioners are used to collect the relevant data required for the formation of sub-index functions. Collectively, the set of information from expert opinions is converged into rating curves, which are further converted into linear or non-linear sub-index functions. Since its inception in 1970, the Rand Corporation's Delphi Technique has been widely adopted in the establishment of various water quality indices. Indices that include the National Sanitation Foundation (NSF) Index, the Scottish Research Development Department (SRDD) Index, Ross' Index, the Oregon Index, House's Index, 
the Smith Index and Almeida's Index [10, 12, 38, 39, 42, 43, 70].

\section{Use of Water Quality Standards}

The second method involves the use of water quality legislative standards to establish sub-index functions. Permissible water quality parameter concentration levels are used to derive the rating curves, which can eventually be transformed to sub-index functions. Unlike the Delphi method, the important points of the rating curves are obtained using the permissible limits for each particular parameter, in understanding of the intended use of the water body. Actual measured water quality parameter values can be translated to sub-index values using three methods, namely linear interpolation rescaling, categorical scaling and comparison with permissible limits. The first technique, known as linear interpolation rescaling, relays an identical range of subindex values, normally between zero to one-hundred or zero to one. In similar fashion, the establishment of water quality classification follows a sequential order, which can be Class 1, Class 2, ...Class 5. Thereafter, using the permissible limits from the minimum to the maximum, each limit corresponding to the relevant water quality classification and is assigned to the corresponding subindex number [5]. For example; considering permissible limits of 20, 30, 40, 80 and $120 \mathrm{mg} / \ell$, and sub-index range of $100,75,50,25$ and 1 ; then the pairing of the key points can observe the following sequence: Class 1 (20:100), Class 2 (30:75), ...Class 5 (120:1). These paired set of data are the key points of the rating curve and are the basis at which sub-index functions are developed. If the actual parameter value falls between two classes, the linear interpolation method is used to obtain the actual sub-index value. The following general equations are applicable to this particular approach [5]:

$$
\begin{aligned}
& s_{i}=s_{1}-\left[\left(s_{1}-s_{2}\right)\left(\frac{x_{i}-x_{1}}{x_{2}-x_{1}}\right)\right] \\
& s_{i}=s_{1}-\left[\left(s_{1}-s_{2}\right)\left(\frac{x_{1}-x_{i}}{x_{1}-x_{2}}\right)\right]
\end{aligned}
$$

...where $s_{i}$ is the $i^{\text {th }}$ sub-index value; $s_{1}$ and $s_{2}$ are the sub-index values for the upper and lower classes, respectively; $x_{i}$ is the $i^{\text {th }}$ parameter value; and $x_{1}$ and $x_{2}$ are values of permissible limits for upper and lower class. In the case that a parameter decreases the level of water quality with an increase in parameter value, then Eq. (1) is applicable. Otherwise, Eq. (2) can be adopted when a parameter increases the level of water quality with an increase in parameter value [5]. The second technique is the categorical scaling method, when actual parameter values are transformed to sub-indices using constant values of either zero or one. The sub-index value of zero is assigned to a parameter with concentration levels exceeding the permissible standard, whereas the sub-index value of one is assigned to a parameter with concentration levels below the permissible limits [5]. The following two mathematical functions are used for this technique:

$$
\begin{aligned}
& s_{i}=0 \text { if } x_{i} \text { is well above permissible limits } \\
& s_{i}=1 \text { if } x_{i} \text { is well below permissible limits }
\end{aligned}
$$

...where $s_{i}$ is the $i^{t h}$ sub-index value and $x_{i}$ is the $i^{t h}$ actual parameter value. The third and last approach involves comparing the actual measured parameter values with the legislative standards. In understanding the permissible limits, sub-indices are generated according to the degree of water quality (from the worst to the highest), and the sub-index values range from zero to one. The sub-index values are computed using Eq. (5):

$$
s_{i}=\frac{x_{i}}{x_{\max }}
$$

...where $s_{i}$ is the $i^{\text {th }}$ sub-index value; $x_{i}$ is the $i^{\text {th }}$ actual parameter value $(\mathrm{mg} / \ell)$; and $x_{\text {max }}$ is the maximum value of the permissible limit $(\mathrm{mg} / \ell)$.

\section{Statistical Methods}

In this approach, the key points of the rating curves are developed through statistical analysis of historical parameter data. This technique relays on the statistical characteristics like the mean values and various quantiles of the parameters measured over a long period of time. Various water quality index developers have successfully used this method (developers like Hallock [13], and Dunnette [39], Bhargava [69]). Upon establishment of sub-index functions, the sub-index value has to be factored into the final index, which can be achieved by multiplying the sub-index values with assigned parameter weightage. Establishing such parameter weights is discussed in the subsequent section of this review.

\section{Establishing Weights}

Each parameter has a different effect on water classification, hence weighting factors are used to reflect the influence of each parameter on the index model. These mathematical tools are assigned to each water quality variable based on the level of significance and their influence on the overall index value $[5,56]$. In general, weighting factors are established as either equal or unequal weights. Equal weights are practical if all the water quality parameters are regarded as equally important, whereas unequal weights are effective where some parameters are regarded as being more or less influential than others [5].

A limited number of index developers have adopted the use of equal weights because of the possibilities of unfairness in assigning the weighting factors. Besides, if due diligence is not exercised, unequal weights 
could promote sensitivity of the index model, favoring the heavily weighted water quality variables [5]. Such biasness brings about the element of doubt towards the application of unequal weights. This being said, appropriate measures should be taken in selecting the most suitable technique of developing unequal weights - a method that will minimize prejudice and ratify the integrity of the index model.

Similar to the selection of parameters and the development of sub-indices, there are also participatorybased methods available for establishing weights, and the most commonly used are the Analytical Hierarchy Process (AHP) and the Rand Corporation's Delphi Technique (Delphi Method):

(a) Analytical Hierarchy Process (AHP): a mature and easy concept which has been broadly employed in many other different fields, other than water quality index development. The concept allows for the incorporation of both quantitative and qualitative aspects in the decision-making process. Expert opinion is gathered through "pair-wise comparison matrices," in which the experts are required to present their preference by comparing numerous alternatives. AHP is a very useful method of establishing weights for either individual or aggregated water quality variables. Ocampo-Duque et al. [71] and Gazzaz et al. [24] have both implemented AHP to generate weights for calculating water quality index.

(b) Rand Corporation's Delphi Technique (Delphi Method): using questionnaires, water specialists compare relative water quality parameters using a scale of one (highest) to five (lowest). All the expert ratings are combined and arithmetic mean values are calculated, which are later converted to weight ratings between zero (lowest impact weight) to one (most influential parameter). The procedure was introduced by Horton [14], later improved by Brown et al. [10], and since then, the Delphi Method has been widely employed in various water quality indices in order to produce comparative weights of the selected parameters.

Notably, for most water quality indices, the total weight (the summation of all the weights of the selected parameters) adds up to a unity (1), the reason being that the combined effect of water quality parameters should not exceed $100 \%$ [11]. Otherwise, the aggregation of sub-indices will be compromised, and deem the water quality index dysfunctional.

\section{Aggregation of Sub-Indices}

The aggregation of sub-indices is performed by mathematical functions. These equations integrate subindex values of selected critical parameters in relation to the assigned weights, and obtain the overall water quality status, which is normally presented as a unit-less number. Their application is governed by the degree of accuracy required and whether the parameter weights are either equally or unequally defined. The aggregation process may occur in sequential phases depending on whether an index has aggregated sub-indices or not. Although there are various aggregation techniques available, the common aggregation methods are the additive (arithmetic) and multiplicative (geometric) methods [5]. Further details of existing aggregation techniques, including various mathematical structures considered for the development of water quality indices (WQIs), are discussed separately and documented elsewhere.

\section{Water Classification and Index Scores}

Water quality index scores can be classified in two different ways. The first approach is whereby the index value increases with the increase of contamination level. This approach is referred to as the increasing scale index. The second approach is where the index value decreases with the degree of pollution. This approach is referred to as the decreasing scale index [15]. Nevertheless, the purpose of scaling is the same,

Table 1. Typical WQI classification for increasing scale index.

\begin{tabular}{|c|c|c|c|c|c|c|}
\hline \multirow{3}{*}{ Class } & \multicolumn{6}{|c|}{ Increasing scale water quality indices } \\
\hline & \multicolumn{2}{|c|}{ House, Bordalo \& Carvalho WQI } & \multicolumn{2}{|c|}{ CCME WQI } & \multicolumn{2}{|c|}{ Universal \& Vaal WQI } \\
\hline & Rank & Index score & Rank & Index score & Rank & Index score \\
\hline Class 1 & Very good & 91 to 100 & Excellent & 95 to 100 & Excellent & 95 to 100 \\
\hline Class 2 & Good & 71 to 90 & Good & 80 to 94 & Good & 75 to 94 \\
\hline Class 3 & Reasonable & 51 to 70 & Fair & 65 to 79 & Fair & 50 to 74 \\
\hline Class 4 & Polluted & 26 to 50 & Marginal & 45 to 64 & Marginal & 25 to 49 \\
\hline Class 5 & Badly polluted & 10 to 25 & Poor & 0 to 44 & Poor & 0 to 24 \\
\hline
\end{tabular}

Source: Banda [11], CCME [28], Boyacioğlu [50], Carvalho, et al. [53], Bordalo, et al. [72]. Notes: House WQI: House's water quality index (United Kingdom), Bordalo WQI: Bordalo et al water quality index (Iberian Peninsula: Portuguese-Spanish Border), Carvalho WQI: Carvalho et al water quality index (Portugal), CCME WQI: Canadian Council of Ministers of the Environment WQI (Canada), Universal WQI: Universal water quality index - Boyacioğlu index (Turkey) and Vaal WQI: Vaal water quality index (South Africa) 
Table 2. Typical WQI classification for decreasing scale index.

\begin{tabular}{|c|c|c|c|c|c|c|}
\hline \multirow{2}{*}{ Class } & \multicolumn{4}{|c|}{ Decreasing scale water quality indices } \\
\cline { 2 - 7 } & Rank & Index score & Rank & Index score & Rank & Index score \\
\cline { 2 - 7 } & Excellent & 0 to 3 & Excellent & $<50$ & Excellent & 0 to 25 \\
\hline Class 1 & Good & 4 to 17 & Good & 50.1 to 100 & Good & 26 to 50 \\
\hline Class 2 & Fair & 18 to 43 & Poor & 100.1 to 74 & Bad & 51 to 75 \\
\hline Class 3 & Borderline & 44 to 59 & Very poor & 25 to 49 & Very bad & 76 to 100 \\
\hline Class 4 & Poor & 60 to 100 & Unsuitable & $>300$ & Unfit & 100 and above \\
\hline
\end{tabular}

Source: Zandbergen and Hall [73], Rao, et al. [74], Vasanthavigar, et al. [75], Rao and Nageswararao [76], Vatkar, et al. [77]. Notes: BCWQI: British Columbia water quality index (Canada), Rao WQI: Rao and Nageswararao water quality index (India), Vatkar WQI: Vatkar et al water quality index (India), Vasanthavigar WQI: Vasanthavigar et al water quality index (India) and Rao et al WQI: Rao et al water quality index (India)

as both indices reflects water quality based on pollution levels [11]. The assignment of water quality index values to classes of water quality is termed "categorization" or "classification," and indicates an imperative but somewhat subjective process. Classification should be based on the best available information, expert judgment, and the general public's expectations of water quality [28]. Normally, water quality index values are between zero and 100 and classified in categories ranging from Class 1 to Class 5. The meaning of the index values and classes depends on whether the model is an increasing or decreasing scale index, and typical examples are included in Tables 1 and 2 for increasing and decreasing scale indices respectively.

A major gap identified in most of the water quality classification scales is that not all possible index scores are accommodated in various WQ classification systems reviewed under this study. For instance, considering a classification schema by Rao, et al. [74], index score values between 25-26, 50-51, and 75-76 cannot be categorized unless otherwise the final index score is rounded to a whole number (which is not the case with most of the research work reviewed under this chapter). Some of the water quality indices with similar challenges includes Banda [11], Kannel et al. [49], Sharma et al. [56], Rao and Nageswararao [76], Ramakrishnaiah et al. [78], Al Obaidy et al. [79], Yadav et al. [80], Khanna et al. [81], Bhadra et al. [82], Meher et al. [83], AL-Sabah [84], Sudha et al. [85], Wanda et al. [86], Abdel-Satar et al. [87], and Ewaid and Abed [88]. In some instances, possible index scores fall within two categories: for example index scores of $25,50,70$ and 90

Table 3. Index score classification for Martínez de Bascarón WQI.

\begin{tabular}{|c|c|c|}
\hline & Water quality classification & \multirow{2}{*}{ Index score } \\
\hline & Description of rank and classification & \\
\hline & Class I - Good water quality & \multirow{2}{*}{$\begin{array}{l}91 \leq \text { Index } \leq \\
100\end{array}$} \\
\hline & $\begin{array}{l}\text { Water quality is protected with a virtual absence of threat or impairment; conditions very close to natural or pris- } \\
\text { tine levels }\end{array}$ & \\
\hline \multirow[t]{2}{*}{2} & Class II - Acceptable water quality & \multirow[b]{2}{*}{$61 \leq$ Index $<91$} \\
\hline & $\begin{array}{l}\text { Water quality is usually protected with only a minor degree of threat or impairment; conditions rarely depart } \\
\text { from natural or desirable levels }\end{array}$ & \\
\hline \multirow[t]{2}{*}{3} & Class III - Regular water quality & \multirow[b]{2}{*}{$31 \leq \operatorname{Index}<61$} \\
\hline & $\begin{array}{l}\text { Water quality is usually protected but occasionally threatened or impaired; conditions sometimes depart from } \\
\text { natural or desirable levels }\end{array}$ & \\
\hline \multirow[t]{2}{*}{4} & Class IV - Bad water quality & \multirow{2}{*}{$16 \leq$ Index $<31$} \\
\hline & Water quality is frequently threatened or impaired; conditions often depart from natural or desirable levels & \\
\hline \multirow[t]{2}{*}{5} & Class V - Very bad water quality & \multirow{2}{*}{$0 \leq$ Index $<16$} \\
\hline & Water quality is almost always threatened or impaired; conditions usually depart from natural or desirable levels & \\
\hline
\end{tabular}

Source: Abrahão, et al. [94]. Notes: Class 1 index values (excellent) can only be obtained if all measurements are within objectives virtually all of the time. 
on a scale of 'very bad' (0-25), 'bad' (25-50), 'medium' (50-70), 'good' (70-90) and 'excellent' (90-100). Index score 25 falls under the 'very bad' and 'bad' categories, whereas index score 50 falls under the 'bad' as well as the 'medium' categories, and so forth. Practical examples of this scenario are water classification scales developed by Luzati and Jaupaj [3], Hamid et al. [54], Guettaf et al. [60], Vatkar et al. [89], Kalyani et al. [90], and Shah and Joshi [91]. Zhao et al. [20], Abtahi et al. [57], García-Ávila et al. [63], Al-Janabi et al. [92], and Al Obaidy et al. [93] attempted to resolve the problem by minimizing the difference between classes to a decimal fraction. Although the problem has been minimized, the fact remains that the categorization schema does not accommodate all the achievable index scores. It is then crucial that the use of logical linguistic descriptions (like less than, equal to and greater than) be adopted to allow for the inclusion of all possible index values. and Sutadian et al. [65], Abrahão et al. [94], Rabee et al. [95], and Rubio-Arias et al. [96] are good examples of water categorization schema with appropriate mathematical functions that encompass all possible index values.

\section{Discussion}

The main objective of WQIs is to convert multiple parameter data into information that is understandable by both technical and non-technical personnel. The ability of WQIs to synthesize complex scientific data into simple and easily understood formats makes them the most fundamental and indispensable elements of water quality monitoring agenda. Hence, they are universally acknowledged as a "lifeline" for water quality studies, and their development continues as an on-going affair. Various methods and procedures are considered when developing water quality indices, but the traditionally applied procedure involves: (i) selection of the significant water quality parameters, (ii) formation of sub-indices, (iii) establishing relative parameters weights, (iv) aggregation of the sub-indices, and (v) assigning index scores to a water classification schema. Each step in the development of water quality indices has alternative methods to consider. It is then critically important to select the most appropriate of each alternative. Despite having scientific knowhow of water quality models, WQI developers should apply due diligence and avoid subjective judgements and biasness in the process of developing water quality indices, otherwise the water quality index will inherit such problems and be deemed dysfunctional.

\section{Conclusion}

WQIs are not designed for broad application, but they are customarily developed to accommodate specific water quality parameters - only those regarded as the most significant water quality variables. Therefore,
WQIs cannot evaluate the quality of water for all the applications, and neither can they outline all the water quality hazards, nor can they deliver a complete and comprehensive analysis on water quality; rather they can only provide a quick holistic guide necessary to evaluate water quality trends. However, the most challenging aspect is that water quality indices are developed for a particular region and are source-specific as there is no single water quality index that has been globally accepted. Which then perhaps becomes the ultimate goal - to explore and delineate the possibilities of breaking such limitations, and witness the birth of a robust water quality index that can be applied across various watersheds.

\section{Acknowledgements}

We extend special gratitude to the research office staff of the University of KwaZulu-Natal for supporting this research publication.

\section{Conflicts of Interest}

The authors declare no conflict of interest.

\section{References}

1. SARKAR C., ABBASI S.A. Qualidex - a new software for generating water quality indice. Environmental Monitoring and Assessment. 119 (1), 201, 2006.

2. POONAM T., TANUSHREE B., SUKALYAN C. Water quality indices - important tools for water quality assessment: a review. International Journal of Advances in Chemistry. 1 (1), 15, 2015.

3. LUZATI S., JAUPAJ O. Assessment of Water Quality Index of Durresi-Kavaja Basin, Albania. Journal of International Environmental Application \& Science. 11 (3), 277, 2016.

4. LUMB A., SHARMA T., and BIBEAULT J.-F. A review of genesis and evolution of water quality index (WQI) and some future directions. Water Quality, Exposure and Health. 3 (1), 11, 2011.

5. SUTADIAN A.D., MUTTIL N., YILMAZ A.G., and PERERA B. Development of river water quality indices a review. Environmental Monitoring and Assessment. 188 (1), 58, 2016.

6. PAUN I., CRUCERU L.V., CHIRIAC L.F., NICULESCU M., VASILE G.G., MARIN N.M. Water Quality Indicesmethods for evaluating the quality of drinking water. in 19th INCD ECOIND International Symposium - SIMI 2016, "The Environment and the Industry". Bucharest, Romania: ECOIND, 2016.

7. CHAPMAN D.V. Water quality assessments: a guide to the use of biota, sediments, and water in environmental monitoring. 2 ed. Cambridge Great Britain: University Press. 651, 1996.

8. PALANISAMI K. Water markets as a demand management option: potentials, problems and prospects. Strategic Analyses of the National River Linking Project (NRLP) of 
India. Promoting Irrigation Demand Management in India: Potentials Problems and Prospects. 3, 47, 2009.

9. WORLD HEALTH ORGANISATION. GEMS/WATER 1990-2000: the challenge ahead, in Prevention of Environmental Pollution Unit, Global Environment Monitoring System and UNEP/WHO/UNESCO/WMO Programme on Global Water Quality Monitoring and Assessment. World Health Organisation: Geneva. 68, 1991.

10. BROWN R.M., MCCLELLAND N.I., DEININGER R.A., TOZER R.G. A water quality index - Do we dare? Water and Sewage Works. 117 (10), 339, 1970.

11. BANDA T.D. Developing an equitable raw water pricing model: The Vaal case study, in Department of Civil Engineering Tshwane University of Technology: Pretoria, South Africa. 268, 2015,

12. ALMEIDA C., GONZÁLEZ S.O., MALLEA M., GONZÁLEZ P. A recreational water quality index using chemical, physical and microbiological parameters. Environmental Science and Pollution Research. 19 (8), 3400, 2012.

13. HALLOCK D. A water quality index for ecology's stream monitoring program. Environmental Assessment Program. Olympia WA: Washington State Department of Ecology Publications. 23, 2002.

14. HORTON R.K. An index number system for rating water quality. Journal of Water Pollution Control Federation. 37 (3), 300, 1965.

15. ABBASI T., ABBAS, S.A. Water quality indices. Elsevier. 353, 2012.

16. FU L., WANG Y. Statistical tools for analyzing water quality data, in Water Quality Monitoring and Assessment, Voudouris, Editor. InTech: Rejeka, Croatia. 143, 2012.

17. WALSH P., WHEELER W. Water quality index aggregation and cost benefit analysis. National Center for Environmental Economics, NCEE. \#12-05, 1, 2012.

18. TYAGI S., SHARMA B., SINGH P., DOBHAL R. Water quality assessment in terms of water quality index. American Journal of Water Resources. 1 (3), 34-38, 2013.

19. MAHAPATRA S., SAHU M., PATEL R., PANDA B.N. Prediction of water quality using principal component analysis. Water Quality, Exposure and Health. 4 (2), 93, 2012.

20. ZHAO Y., XIA X.H., YANG Z.F., WANG F. Assessment of water quality in Baiyangdian Lake using multivariate statistical techniques. Procedia Environmental Sciences. 13, 1213, 2012.

21. WAN J., BU H., ZHANG Y., MENG W. Classification of rivers based on water quality assessment using factor analysis in Taizi River basin, northeast China. Environmental earth sciences. 69 (3), 909, 2013.

22. LERMONTOV A., YOKOYAMA L., LERMONTOV M., MACHADO M.A.S. River quality analysis using fuzzy water quality index: Ribeira do Iguape river watershed, Brazil. Ecological Indicators. 9 (6), 1188, 2009.

23. SINGH K.P., BASANT A., MALIK A., JAIN G. Artificial neural network modeling of the river water quality - a case study. Ecological Modelling. 220 (6), 888, 2009.

24. GAZZAZ N.M., YUSOFF M.K., ARIS A.Z., JUAHIR H., RAMLI M.F. Artificial neural network modeling of the water quality index for Kinta River (Malaysia) using water quality variables as predictors. Marine Pollution Bulletin. 64 (11), 2409, 2012.

25. SCANNAPIECO D., NADDEO V., ZARRA T., BELGIORNO V. River water quality assessment:
A comparison of binary- and fuzzy logic-based approaches. Ecological Engineering. 47 (0), 132, 2012.

26. CORDOBA G.A.C., TUHOVČÁK L., TAUŠ M. Using Artificial Neural Network Models to Assess Water Quality in Water Distribution Networks. Procedia Engineering. 70: 399, 2014.

27. EUROPEAN UNION. Council Directive relating to the quality of water intended for human consumption, in Council Directive 80/778/EEC, European Union, Editor: Brussels. 19, 1995,

28. CCME. Canadian water quality guidelines for the protection of aquatic life: CCME Water Quality Index 1.0 Technical Report. Canadian Environment Quality Guidelines. 1.0, 1, 2001.

29. WORLD HEALTH ORGANIZATION. Ammonia in drinking water. Guidelines for drinking water quality, ed. World Health Organization. Geneva, Switzerland: Worl Health Organization Library. 4, 2003.

30. WORLD HEALTH ORGANIZATION. Chloride in drinking water. Guidelines for drinking water quality, ed. World Health Organization. Geneva, Switzerland: World Health Organization Library. 4, 2003.

31. WORLD HEALTH ORGANIZATION. Guidelines for drinking water quality. 4th ed, ed. World Health Organization. Geneva, Switzerland: World Health Organization. 564, 2011.

32. EFSA. Health risk of ammonium released from water filters. EFSA Journal. 10 (10), 19, 2012.

33. SREBOTNJAK T., CARR G., DE SHERBININ A., RICKWOOD C. A global water quality index and hot-deck imputation of missing data. Ecological Indicators. 17, 108, 2012.

34. LIU W.-C., YU H.-L., CHUNG C.-E. Assessment of water quality in a subtropical alpine lake using multivariate statistical techniques and geostatistical mapping: a case study. International journal of environmental research and public health. 8 (4), 1126, 2011.

35. SHYU G.-S., CHENG B.-Y., CHIANG C.-T., YAO P.-H., CHANG T.-K. Applying factor analysis combined with kriging and information entropy theory for mapping and evaluating the stability of groundwater quality variation in Taiwan. International Journal of Environmental Research and Public Health. 8 (4), 1084, 2011.

36. SUN R., AN D., LU W., SHI Y., WANG L., ZHANG C., ZHANG P., QI H., WANG Q. Impacts of a flash flood on drinking water quality: case study of areas most affected by the 2012 Beijing flood. Heliyon. 2 (2), e00071, 2016.

37. BROWN R., MCCLELLAND N., DEININGER R., LANDWEHR J. Validating the WQI. in The paper presented at national meeting of American Society of Civil Engineers on Water Resources Engineering Washington, DC, 1973.

38. SRDD. Development of a water quality index, in Applied Research \& Development Report Number ARD3, Scottish Research Development Department Engineering Division, Editor. Scottish Research Development Department Engineering Division,: Edinburg, UK. 61, 1976,

39. DUNNETTE D. A geographically variable water quality index used in Oregon. Journal (Water Pollution Control Federation). 51 (1), 53, 1979.

40. CUDE C.G. Oregon water quality index: a tool for evaluating water quality management effectiveness. JAWRA Journal of the American Water Resources Association. 37 (1), 125, 2001.

41. MARTÍNEZ DE BASCARÓN G. Establishment of a methodology for the determination of water quality 
(Establecimiento de una metodologia para conocer la calidad del agua). Boletín Informativo del Medio Ambiente. 9, 30, 1979.

42. HOUSE M.A. Water quality indices, in Civil Engineering. Middlesex Polytechnic, London: Queensway Enfield, London. 495, 1986,

43. SMITH D.G. Water quality indexes for use in New Zealand's rivers and streams. National Water \& Soil Conservation Authority. New Zealand, Water Quality Centre Publication. (12), 1987.

44. TYSON J., HOUSE M. The application of a water quality index to river management. Water Science and Technology. 21 (10-11), 1149, 1989.

45. HOUSE M.A. Water quality indices as indicators of ecosystem change. Environmental Monitoring and Assessment. 15 (3), 255, 1990.

46. PESCE S.F., WUNDERLIN D.A. Use of water quality indices to verify the impact of Córdoba City (Argentina) on Suquía River. Water Research. 34 (11), 2915, 2000.

47. LIOU S.M., LO S.L., WANG S.H. A generalized water quality index for Taiwan. Environmental Monitoring and Assessment. 96 (1-3), 35, 2004.

48. DEBELS P., FIGUEROA R., URRUTIA R., BARRA R., NIELL X. Evaluation of water quality in the Chillán River (Central Chile) using physicochemical parameters and a modified water quality index. Environmental Monitoring and Assessment. 110 (1), 301, 2005.

49. KANNEL P.R., LEE S., LEE Y.-S., KANEL S.R., KHAN S.P. Application of water quality indices and dissolved oxygen as indicators for river water classification and urban impact assessment. Environmental Monitoring and Assessment. 132 (1), 93, 2007.

50. BOYACIOĞLU H. Development of a water quality index based on a European classification scheme. Water SA. 33 (1), 2007.

51. SÁNCHEZ E., COLMENAREJO M.F., VICENTE J., RUBIO A., GARCÍA M.G., TRAVIESO L., BORJA R. Use of the water quality index and dissolved oxygen deficit as simple indicators of watersheds pollution. Ecological Indicators. 7 (2), 315, 2007.

52. KUMAR D., ALAPPAT B.J. NSF-Water Quality Index: Does It Represent the Experts' Opinion? Practice Periodical of Hazardous, Toxic, and Radioactive Waste Management. 13 (1), 75, 2009.

53. CARVALHO L., CORTES R., BORDALO A.A. Evaluation of the ecological status of an impaired watershed by using a multi-index approach. Environmental Monitoring and Assessment. 174 (1-4), 493, 2011.

54. HAMID A., DAR N.A., BHAT S.U., PANDIT A.K. Water quality index: A case study of Vishav stream, Kulgam, Kashmir. International Journal of Environment and Bioenergy. 5 (2), 108, 2013.

55. KOÇER M.A.T., SEVGILI H. Parameters selection for water quality index in the assessment of the environmental impacts of land-based trout farms. Ecological Indicators. 36, 672, 2014.

56. SHARMA P., MEHER P.K., KUMAR A., GAUTAM Y.P., MISHRA K.P. Changes in water quality index of Ganges river at different locations in Allahabad. Sustainability of Water Quality and Ecology. 3, 67, 2014.

57. ABTAHI M., GOLCHINPOUR N., YAGHMAEIAN K., RAFIEE M., JAHANGIRI-RAD M., KEYANI A., SAEEDI R. A modified drinking water quality index (DWQI) for assessing drinking source water quality in rural communities of Khuzestan Province, Iran. Ecological Indicators. 53, 283, 2015.
58. SINGH S., GHOSH N., KRISHAN G., GALKATE R. THOMAS T., JAISWAL R. Development of an overall water quality index (OWQI) for surface water in Indian context. Current World Environment. 10 (3), 813, 2015.

59. EWAID S.H. Water quality evaluation of Al-Gharraf river by two water quality indices. Applied Water Science. 1, 2016.

60. GUETTAF M., MAOUI A., IHDENE Z. Assessment of water quality: a case study of the Seybouse River (North East of Algeria). Applied Water Science. 7 (1), 295, 2017.

61. TRIKOILIDOU E., SAMIOTIS G., TSIKRITZIS L., KEVREKIDIS T., AMANATIDOU E. Evaluation of water quality indices adequacy in characterizing the physicochemical water quality of lakes. Environmental Processes. $1,2017$.

62. EWAID S.H., ABED S.A., KADHUM S.A. Predicting the Tigris River water quality within Baghdad, Iraq by using water quality index and regression analysis. Environmental Technology \& Innovation. 11, 390, 2018.

63. GARCÍA-ÁVILA F., RAMOS-FERNÁNDEZ L., PAUTA D., QUEZADA D. Evaluation of water quality and stability in the drinking water distribution network in the Azogues city, Ecuador. Data in Brief. 18, 111, 2018.

64. PONSADAILAKSHMI S., SANKARI S.G., PRASANNA S.M., MADHURAMBAL G. Evaluation of water quality suitability for drinking using drinking water quality index in Nagapattinam district, Tamil Nadu in Southern India. Groundwater for Sustainable Development. 6, 43, 2018.

65. SUTADIAN A.D., MUTTIL N., YILMAZ A.G., PERERA B.J.C. Development of a water quality index for rivers in West Java Province, Indonesia. Ecological Indicators. 85, 966, 2018.

66. TIRI A., BELKHIRI L., MOUNI L. Evaluation of surface water quality for drinking purposes using fuzzy inference system. Groundwater for Sustainable Development. 6, 235, 2018.

67. YOUSEFI H., ZAHEDI S., NIKSOKHAN M.H. Modifying the analysis made by water quality index using multi-criteria decision making methods. Journal of African Earth Sciences. 138, 309, 2018.

68. SAID A., STEVENS D.K., SEHLKE G. An innovative index for evaluating water quality in streams. Environmental management. 34 (3), 406, 2004.

69. BHARGAVA D.S. Expression for drinking water supply standards. Journal of Environmental Engineering. 111 (3), 304, 1985.

70. ROSS S. An index system for classifying river water quality. Water Pollution Control. 76 (1), 113, 1977.

71. OCAMPO-DUQUE W., FERRE-HUGUET N., DOMINGO J.L., SCHUHMACHER M. Assessing water quality in rivers with fuzzy inference systems: A case study. Environment International. 32 (6), 733, 2006.

72. BORDALO A.A., TEIXEIRA R., WIEBE W.J. A water quality index applied to an international shared river basin: the case of the Douro River. Environmental Management. 38 (6), 910, 2006

73. ZANDBERGEN P.A., HALL K.J. Analysis of the British Columbia water quality index for watershed managers: a case study of two small watersheds. Water Qual. Res. J. Canada. 33 (4), 1998.

74. RAO C.S., RAO B.S., HARIHARAN A., BHARATHI, N.M. Determination of water quality index of some areas in Guntur District Andhra Pradesh. International Journal of Applied Biology and Pharmaceutical Technology. 1 (1), 79, 2010. 
75. VASANTHAVIGAR M., SRINIVASAMOORTHY K., VIJAYARAGAVAN K., GANTHI R.R., CHIDAMBARAM S., ANANDHAN P., MANIVANNAN R., VASUDEVAN S. Application of water quality index for groundwater quality assessment: Thirumanimuttar sub-basin, Tamilnadu, India. Environmental Monitoring and Assessment. 171 (1-4), 595, 2010.

76. RAO G.S., NAGESWARARAO G. Assessment of ground water quality using water quality index. Archive of Environmental Sciences. 7, 1, 2013.

77. VATKAR Y.S., VATKAR N.S., VATKAR A.S. Assessment of WQI by Weighted Arithmetic Index Method for Engineering Colleges in Kolhapur City, Maharashtra, India. International Journal of Engineering Science and Computing. 6 (8), 2919, 2016.

78. RAMAKRISHNAIAH C., SADASHIVAIAH C., RANGANNA G. Assessment of water quality index for the groundwater in Tumkur Taluk, Karnataka State, India. Journal of Chemistry. 6 (2), 523, 2009.

79. AL OBAIDY A.H.M.J., ABID H.S., MAULOOD B.K. Application of water quality index for assessment of Dokan lake ecosystem, Kurdistan region, Iraq. Journal of Water Resource and Protection. 2 (09), 792, 2010.

80. YADAV A.K., KHAN P., SHARMA S.K. Water Quality Index Assessment ofGroundwater in Todaraisingh Tehsil of Rajasthan State, India-A Greener Approach. Journal of Chemistry. 7 (S1), S428, 2010.

81. KHANNA D., BHUTIANI R., TYAGI B., TYAGI P.K., RUHELA M. Determination of water quality index for the evaluation of surface water quality for drinking purpose. International Journal of Science and Engineering. 1, 09, 2013.

82. BHADRA A.K., SAHU B., ROUT S.P. A study of water quality index (WQI) of the river Brahmani, Odisha (India) to assess its potability. International Journal of Current Engineering and Technology. 4 (6), 4270, 2014.

83. MEHER P.K., SHARMA P., GAUTAM Y.P., KUMAR A., MISHRA K.P. Evaluation of Water Quality of Ganges River Using Water Quality Index Tool. EnvironmentAsia. 8 (1), 2015

84. AL-SABAH B.J. Application of Water Quality Index to Assessment of Tigris River. International Journal of Current Microbiology and Applied Sciences. 5 (10), 397, 2016.

85. SUDHA R.P., UMA R.N., MURALI K., MEIARA J. Assessment of Groundwater Quality Using WQI Method Around Vellalore Municipal Solidwaste Disposal Site in Coimbatore, Tamilnadu, India. International Journal of Chemical Sciences. 14 (1), 229, 2016.
86. WANDA E.M., MAMBA B.B., MSAGATI T.A. Determination of the water quality index ratings of water in the Mpumalanga and North West provinces, South Africa. Physics and Chemistry of the Earth. 92, 70, 2016.

87. ABDEL-SATAR A.M., ALI M.H., GOHER M.E. Indices of water quality and metal pollution of Nile River, Egypt. The Egyptian Journal of Aquatic Research. 43 (1), 21, 2017.

88. EWAID S.H., ABED S.A. Water quality index for AlGharraf River, southern Iraq. The Egyptian Journal of Aquatic Research. 2017.

89. VATKAR Y., KORE S., KORE V., KULKARNI G. Evaluation of Water Quality Indices for the Drinking water of Engineering Colleges in Kolhapur city. International Journal of Science and Engineering Research. 4 (3), 1, 2013.

90. KALYANI R.A., RAO S.G., NAGESHWARAO B., THIRUPATHI B. Water Quality Index in Four Sites of the Cherlapally Lake, Telangana State. International Journal for Innovative Research in Science and Technology. 3 (4), 66, 2016.

91. SHAH K.A., JOSHI G.S. Evaluation of water quality index for River Sabarmati, Gujarat, India. Applied Water Science. 7 (3), 1349, 2017.

92. AL-JANABI Z.Z., AL-OBAIDY A.-H.M.J., AL-KUBAISI A.-R. Applied of CCME Water Quality Index for Protection of Aquatic Life in the Tigris River within Baghdad city. Journal of Al-Nahrain University. 18 (2), 99, 2015.

93. AL OBAIDY A., AWAD E.S., KADHEM A.J., AL MASHHADY A. Evaluating water quality of Mahrut River, Diyala, Iraq for irrigation. Engineering \& Technology Journal. 33 (4), 830, 2015.

94. ABRAHÃO R., CARVALHO M., DA SILVA JR W., MACHADO T., GADELHA C., HERNANDEZ M. Use of index analysis to evaluate the water quality of a stream receiving industrial effluents. Water SA. 33 (4), 2007.

95. RABEE A.M., AL-FATLAWY Y.F., NAMEER M. Using pollution load index (PLI) and geoaccumulation index (I-Geo) for the assessment of heavy metals pollution in Tigris river sediment in Baghdad Region. Al-Nahrain Journal of Science. 14 (4), 108, 2011.

96. RUBIO-ARIAS H., CONTRERAS-CARAVEO M., QUINTANA R.M., SAUCEDO-TERAN R.A., PINALESMUNGUIA A. An overall water quality index (WQI) for a man-made aquatic reservoir in Mexico. International journal of environmental research and public health. 9 (5), 1687, 2012. 
